\title{
Palabras del señor Director del Instituto Nacional de Salud, doctor Moisés Wasserman Lerner
}

Hace 80 años, dos visionarios, los doctores Bernardo Samper Sordo y Jorge Martínez Santamaría, fundaron un laboratorio privado con todas las características de laboratorio de salud pública. Producían algunos insumos que no se podían conseguir en el país por los sistemas de transporte y los mecanismos comerciales primitivos de principios de sigio. Manejaron el laboratorio con un altruísmo admirable, al extremo que uno de ellos murió prematuramente, infectado por la bacteria que cultivaba. En 1925, el Estado compró el laboratorio y desde entonces lo ha acompañado, a través de sus metamorfosis, el carácter de nacional con todas sus implicaciones filosóficas y de servicio público.

La producción de biológicos siempre fue una preocupación central, pero ha cambiado según las necesidades. La viruela ya se erradicó de Colombia y del mundo (y tuvimos que ver con eso); produjimos la primera vacuna contra la fiebre aftosa, hoy ya rutina de Vecol; durante la Segunda Guerra Mundial produjimos quinina cuando Japón bloqueó su suministro a occidente. Hemos construido acueductos rurales, hoy en manos de las comunidades y los municipios; hicimos el control técnico de medicamentos y alimentos que hoy es función del Invima. Siempre cambiando de acuerdo con las necesidades que impone el momento.

Hoy, nuestra imagen se consolida cada vez más como la de una institución de ciencia y tecnología en salud. La tecnología que usamos es de frontera, nuestros resultados son novedosos en cualquier contexto que se vean. Nuestro producto principal es el conocimiento y nuestra actividad central es su generación. Conocimiento de nuestras patologías, de su biología y de las realidades económicas y sociales que las acompañan y conocimiento de las formas de difusión de la enfermedad y de su control. Ese conocimiento se manifiesta de forma diferente en las diferentes reparticiones. En algunas se difunde como artículos en la prensa científica nacional e internacional. Con ellos contribuimos al acerbo de conocimientos del país y de la humanidad. Ellos construyen en la nación una capacidad de respuesta a los retos futuros. Formamos investigadores e influimos en el pensamiento y la cultura del país. En otras reparticiones, el conocimiento origina formas eficientes y racionales de controlar la enfermedad. Difunde por todas las regiones del país la mejor tecnología de diagnóstico y vigila su correcta aplicación. Explica la dinámica de las epidemias y ayuda a diseñar intervenciones adecuadas. Otros, entre nosotros, producen el conocimiento embotellado y empacado, como un producto biotecnológico para prevenir la enfermedad y la muerte. Producto que es usado por el Ministerio en sus campañas masivas de vacunación.

El año pasado llevamos a cabo 61 proyectos; de ellos, 19 cofinanciados por otras entidades nacionales y 15 por agencias internacionales. Publicamos 12 artículos en la prensa internacional indexada, 30 en la nacional y más de 50 informes técnicos y epidemiológicos. Se dictaron 27 cursos; 31 investigadores de otros institutos se formaron con nosotros. Produjimos $14{ }^{\prime} 000.000$ de dosis de vacunas de verdad, que fueron aplicadas por el Ministerio de Salud a los niños colombianos. A pesar de eso figuramos poco, no se oye hablar mucho de nosotros y eso está realmente bien. igualmente silenciosos son la mayoría de sus funcionarios, de excepcionales calidades académicas y humanas. Un viejo proverbio bíblico dice que sólo las vasijas vacías hacen ruido.

Nuestra vocación y el destino para el cual preparamos al Instituto es, pues, indudablemente la ciencia y somos nosotros quienes tenemos la responsabilidad de enfrentar el "reto de la 
modernidad", la entrada al siglo XXI. La Comisión Carnegie de Ciencia, Tecnología y Gobierno (y, por favor, pongan atención a ese nombre tan interesante), dirigida por el expresidente Jimmy Carter, decía en 1992 que las naciones se dividían en las científicamente ricas y las científicamente pobres.

Todos los desarrollos fundamentales esperados en el mundo dependen de la capacidad que tengan los países para generar, absorber y usar ciencia y tecnología de vanguardia. Para el Estado, la inversión en ciencia debe entenderse como la construcción de su energía potencial. El desarrollo no se mide como la ausencia de problemas en una sociedad. Si así fuera, el Principado de Mónaco sería el más desarrollado de los países y los Estados Unidos estarían muy abajo en la escala. El desarrollo se mide como el potencial de respuesta de la sociedad ante los problemas que surgen y cambian todo el tiempo. Ese potencial, sus elementos cognititivos, su estructura instrumental y su planta humana es la ciencia. Toda postergación en los esfuerzos para su construcción y consolidación es una postergación del desarrollo. Resignarse a la incapacidad de hacer ciencia es asumir el subdesarrollo como vocación.

No se si existe un sistema econométrico que permita calcular el costo ahorrado por lo que pudo haber pasado y no pasó. Sólo ese sistema podría evaluar en forma justa nuestro aporte a la sociedad. Hoy, por ejemplo, la Organización Panamericana de la Salud estudia por qué en Colombia el cólera no fue la tragedia humana y económica que fue en nuestros vecinos, con cientos de miles de enfermos y miles de muertos. Estoy seguro que entre las causas encontrarán que a este Instituto no le tomó más de un par de semanas montar un sistema de diagnóstico y vigilancia efectivo, que el Ministerio de Salud contaba con una excelente capacidad de análisis epidemiológico y de intervención y que habíamos reflexionado sobre el problema. Es decir que poseíamos un gran potencial de respuesta.

Hay otro aspecto de la ciencia que no puedo dejar de mencionar hoy, y es la profunda influencia que ella tiene en la cultura y en la sociedad. La democracia liberal occidental y la ciencia moderna son hijas de los mismos padres. Primo Levi, describiendo el ascenso del fascismo en Italia, escribe: "La química y la física de las que nos alimentábamos, además de ser una nutrición vital, eran los antídotos contra el fascismo porque eran claras, distintas y verificables en cada paso y no el tejido de mentiras y vacuidad de la ideología de Musolini presentada por el radio y los periódicos". La posición de Primo Levi es clara, el pensamiento científico riguroso era un antídoto contra el fascismo. Jacob Bronowski lo pone en otros términos: "La ciencia impone condiciones inescapables para su práctica que compelen una ética. Lejos de ser neutral con respecto a valores humanos, la ciencia como el arte requiere libertad, honestidad y tolerancia para generar conocimiento con originalidad y creatividad". Si bien es claro que la ciencia en su condición actual no es suficiente para explicar la condición humana, es claro también que el ejercicio de la razón es absolutamente necesario para hacerlo.

La ciencia es, pues, un aliado indispensable del estado democrático, libre y moderno. Pero, para jugar su papel eficientemente necesita de su decidido apoyo y estímulo. Son duros los números escuetos que muestran cómo los Estados Unidos invierten en investigación cada día de este año lo que nosotros invertiremos en cuatro años. Pero, aunque la inversión es muy importante no lo es todo. En una época de grandes dificultades fiscales como la que pasamos, se puede de todas formas lograr avances significativos en la capacidad operativa del sistema.

Nadie duda hoy que la Ley 29 impulsada por el presidente Barco partió en dos la historia de la ciencia colombiana. Sin embargo, pocos dudan también que ya se quedó corta y que se hace necesario promulgar una nueva legislación de avanzada. Es necesario crear mecanismos administrativos ágiles y competitivos. Es fundamental estimular efectivamente la vinculación del sector privado, hoy ausente del esfuerzo. Es urgente crear la nueva naturaleza jurídica de institutos públicos de investigación que, con un régimen paralelo al que se le dió a la universidad pública, 
pueda mejorar substancialmente la competitividad del Estado que es, aun en las sociedades más desarrolladas e industrializadas, el principal financiador, gestor y ejecutor de la ciencia.

Sabemos, señor Presidente, que dentro de su gobierno se están gestando iniciativas en esa dirección y nosotros, todos los dolientes de la ciencia, las apoyamos irrestrictamente. Esta celebración de 80 años es algo realmente excepcional en nuestro continente, pero nuestros sucesores celebrarán dentro de 20 años el centenario de una gran institución solamente si nosotros, ahora mismo, establecemos las condiciones para la supervivencia y crecimiento de todo el sistema. Tal vez celebren también, el abandono definitivo del grupo de las naciones científicamente pobres.

Santa Fe de Bogotá, 14 de marzo de 1997 